\title{
Social Enterprises' Hybridity in the Concept of Institutional Logics: Evidence from Polish NGOs
}

\author{
Paweł Mikołajczak ${ }^{1}$ (D)
}

Published online: 23 January 2020

(C) The Author(s) 2020

\begin{abstract}
Social enterprises have gained wide recognition as a tool for solving social and environmental problems. They generate new opportunities in the social sphere, while being active in the commercial field. They are hybrid organizations that face many challenges when pursuing frequently conflicting goals. Social enterprises are therefore an expression of the possibility of different institutional logics coexisting as part of the same organization. Social enterprises running a commercial activity and using business-like practices legitimize the market logic, while the social goal of their operation is consistent with the logic of social welfare. Although there an intense discussion takes place in the literature on institutional logics that may affect nonprofits' activity as hybrid organizations, so far the topic has been empirically verified only to a limited extent. The aim of this article is to examine the successful coexistence of the market logic and the social-welfare logic in NGOs acting as social enterprises. On the basis of a representative national survey of 3800 NGOs, including 412 carrying out market sales and thereby referred to as social enterprises, a one-factor analysis of variance was carried out. The obtained findings of the study indicate that social enterprises acting as non-governmental organizations successfully combine the market and the social-welfare logics.
\end{abstract}

Keywords Institutional logics · Hybridity $\cdot$ Social enterprises · NGOs

Paweł Mikołajczak

pawel.mikolajczak@ue.poznan.pl

1 Department of Money and Banking, Poznań University of Economics and Business, Aleje Niepodległości 10, 61-875 Poznań, Poland

\section{Introduction}

Social enterprises have gained wide recognition as a tool for solving social and environmental problems. They generate new opportunities in the social sphere, while being active in the commercial field. They are hybrid organizations that face many challenges when pursuing frequently conflicting goals. Social enterprises are perceived as an expression of the possibility of different institutional logics coexisting within the same organization. Social enterprises running an effective commercial activity and using business-like practices legitimize the market logic, while the social goal of their operation is in accordance with the logic of social welfare. However, with regard to hybridization, there is a lively debate about tensions within nonprofits between performing business activity effectively and sustaining the original social mission. ${ }^{1}$ Even though a heated discussion is taking place in the literature about institutional logics that may have an impact on the operation of nonprofits as hybrid entities, this area has not been subjected to a detailed empirical scrutiny. This research gap posed a considerable challenge for the present author. It is also impossible to ignore the fact that the literature on the topic concerns primarily NGOs in Anglo-Saxon as well as highly developed European countries, as the literature review clearly indicates. No research in this area has been conducted into the countries of Central and Eastern Europe.

\footnotetext{
1 The definitions that explain social mission are established by those, referring to contribute to the long-standing welfare in a given human community and efficiently catering to basic human needs that existing markets and institutions have failed to satisfy (e.g., Certo and Miller 2008; Peredo and Mclean 2006; Korosec and Berman 2006; Seelos and Mair 2005).
} 
Firstly, a question arises about the characteristics of the functioning of NGOs operating as social enterprises that significantly distinguish them from those non-governmental organizations that do not perform any business activity. Another question is whether non-governmental organizations operating as social enterprises combine successfully market activity and social aims. The answer to these research questions will improve knowledge about the sector, determine the direction of NGOs' development and provide practical implications for their governance and operations.

The aim of this article, therefore, is to examine the successful coexistence of the market logic and the socialwelfare logic in NGOs acting as social enterprises. The article presents two hypotheses. The first one assumes that there are significant distinctions in the way non-governmental organizations operate as social enterprises in comparison with those NGOs that do not perform business activity, which gives them the characteristics of a hybrid organization. The second hypothesis concerns the possibility of a successful coexistence of two different institutional logics within social enterprises.

To attain the paper's goal, on the basis of 3800 NGOs, including 412 NGOs conducting business activity and 3386 not doing so, an ANOVA analysis was carried out.

With regard to the variables, it should be acknowledged that all variables are indicated as an expression of the researched organizations' self-esteem. In consequence, asking the leaders of NGOs with a vested interest how the organizations assess their financial or social achievements could be biased. Another limitation is the use of Likerttype scales, which substantially reduces the availability of information. The present author is aware that the selected and investigated characteristics of social enterprises' hybridity, as well as evidence of a successful coexistence of contradictory institutional logics, do not constitute an entire spectrum of items.

At the initial stage, some key notions related to the institutional logics and hybridity of NGOs operating as social enterprises are explained. Secondly, research methodology-including data, research methods and a systematization of variables-is described. Thirdly, the paper analyzes differences between organizations that perform and those that do not perform business activity and points to the characteristics reflecting a successful coexistence of the market and the social-welfare logics. On this basis, the author draws conclusions and presents suggestions for further research.

\section{Literature Review}

\section{Institutional Logics}

A consequence of NGOs' marketization is the emergence of hybrid entities which successfully combine two fundamentally different types of logic: one related to social welfare and the other to the market. The concept of institutional logics was introduced by Alford and Friedland (1985). These authors pointed to specific contradictions in the functioning of Western societies and described capitalism, political democracy and government bureaucracy as three subordinated institutional categories which determine the way in which particular citizens get involved in political life. Jackall (1988) defines institutional logics as "the complicated, experientially constructed, and thereby contingent set of rules, premiums and sanctions that men and women in particular contexts create and recreate in such a way that their behavior and accompanying perspective are to some extent regularized and predictable."

Thornton and Ocasio (2008) define institutional logics as socially constructed, historical patterns, practice, assumptions, values, beliefs and principles by means of which individuals create their material existence, organize time and space, and give meaning to their social reality.

Thornton (2004) refers logics to the "axial principles of organization and action based on cultural discourses and material practices prevalent in different institutional or societal sectors." Logic constitutes a basis for the application of organizational practices in specific circumstances and in special moments in history. In his other considerations, the author emphasizes that institutional logics play an important role in the company's operation, especially at the organizational level. This is because they support decision makers in solving various types of problems which may be classified according to the dominant logic. They enable managers to focus on their most urgent tasks. Thanks to this, management staff can concentrate on issues that are significant from the viewpoint of institutional logics (Vickers, et al. 2017).

Jay (2013) demonstrated that the actions and thinking of those who participate in an organization do not have to be determined by one dominant logic. Rather, there is an oscillation between logics, and normally conflicts between them are hidden, which allows them to coexist. According to the author, the differences between logics become apparent only at certain points in the organization's lifefor example, when the results of its activity are to be interpreted. For instance, what can be perceived as success from the perspective of the community's logic is not necessarily seen in the same way from the perspective of the market's or government's logic (Thornton et al. 2012). 
Similar results were obtained in a study of audit firms (Lander, et al. 2013). These companies traditionally base their activity on professional logic, personified by the firm's partners. However, growing competition forces these companies increasingly to take into account the commercial (market) logic. These two, partly irreconcilable, logics formulate different expectations concerning the company's strategy and structure. Research results demonstrate that participants in the organization borrow practices from both logics in an eclectic way, depending on the situation they have to address.

In a similar vein, Hensel (2015) points out that in order to understand the way in which an organization and its members operate, one has to analyze the social and institutional context. Distinguishing between the relations occurring in an institutional system is of particular importance because it consists of these logics. Their coexistence, coevolution and conflict make it possible to interpret the dynamics of the institutional field and organizational change. The author also emphasizes that organizational changes within the organization may result from a confrontation between two or more logics in one place. He stresses that "when a given logic gains recognition in society, it also leaves its mark on specific organizations whose actions have until now determined other logics. The most frequently described cases include studies of marketlogic invasions in areas that have so far been influenced by professional logic."

Other studies demonstrate that when different institutional logics formulate different expectations, a hybrid organization may be formed (Pache and Santos 2013). In an inductive comparative case study of four work-integration social enterprises embedded in competing socialwelfare and commercial logics, the authors explore how hybrid organizations, which incorporate competing institutional logics, internally manage the logics that they embody. They indicate that organizations that entered the work-integration field with low legitimacy-because of their embeddedness in the commercial logic-strategically incorporated elements from the social-welfare logic in an attempt to gain legitimacy and acceptance among external cooperating entities without having to engage in costly negotiations.

An organization combining the requirements of various logics is particularly often adopted by NGOs, which should be able to cooperate, on the one hand, with the local community and, on the other, with public administration agencies (for instance, to raise funds or to meet reporting requirements) and with commercial organizations (Battilana and Dorado 2010). The success of such an organization depends on whether it can translate social goals into a language that can be understood by government and business agencies. At the same time, it is essential to be able to meet these agencies' expectations, while making efforts to satisfy the organization's direct clients (Pache and Santos 2013).

It should also be noted that an open conflict between logics may arise. Such a situation usually occurs when an area previously dominated by the social logic is subjected to the market logic (Wry and York 2017). For example, considering the ability to compete with other organizations, Galaskiewicz and Barringer (2012) assess whether social enterprises that combine charity and business logics should present these in an ambiguous, blended form or as segmented, pure types facing different stakeholders. They argue that hybrids that are blended are more likely to outcompete hybrid forms, whose traits evoke contradictory logics. The authors point out that if hybrids are able to signal their "true" identities employing various organizational masques, they will be able to compete as effectively as organizations which are "purer." Skelcher and Smith (2015) point to examples of social enterprises whose blended model is in some respects a unique mix of three logics. These hybrid organizations embody the market logic (a commercial activity based on sales of services), but also reflect a public mission and the government's priorities.

McMullin and Skelcher (2018) have examined ten hybrid French and English nonprofits. They argue that, in France, hybrids are "blended," integrating the state's and the community's institutional logics. In turn, "assimilated" hybrids combining state, community and market logics are found in the English cases. French hybrid organizations aim to benefit society. They are democratically governed, giving priority to people over capital in the distribution of income. They function under a democratic model and have three axes: a plan, a territory and democratic functioning. However, the authors did not find democratic decisionmaking in English blended organizations, although the legal governance structure of English entities is comparable to that of French organizations.

Exploring social enterprises regarding the concept of institutional logics, it should be pointed out that no research has been conducted in this area with regard to the countries of Central and Eastern Europe (CEE). There is also a shortage of significant data in this respect.

The institutional specificity of CEE is largely historically conditioned (Vacekova et al. 2017; Bakoš et al. 2015; Pospísil et al. 2014). While the Central and Eastern European nonprofit sector had to struggle with a difficult process of transition from a centrally governed to a democratic system, the nonprofit sector in the Anglo-Saxon world and in highly developed European countries operated effectively in the well-developed structures of the market economy (Frič 2004). In the Western world, the phenomenon of shifting nonprofits' community-oriented focus 
toward a business model is considered an integral part of neoliberal governance and is usually associated with criticism of neoliberalism in the Anglo-Saxon world (Evans et al. 2005). In post-communist countries, the business-like orientation is embedded as a process of achieving autonomy from the state, which used to be paternalistic in the past (Vacekova et al. 2017).

\section{Hybridity of Social Enterprises}

The aforementioned possibility of different institutional logics coexisting within the same organization finds its expression in the functioning of social enterprises. These are hybrid entities that can combine different logics. When analyzing the hybridity of social enterprises in the context of institutional logics, first of all attention should be given to the categories distinguishing the three sectors identified within the structure of democratic countries' economies, namely the public (state) sector, the for-profit sector and the nonprofit sector (Weisbord 1975). For-profit sector entities, which are driven by market forces, work to maximize their profits. They are owned by shareholders, who expect the organization's performance to be reflected in profits. On the other hand, public-sector entities operate in accordance with the public-benefit principles. They are owned by citizens and the state, and their activities are funded with taxes. Nonprofit organizations, in turn, work toward social and environmental goals. Owned by their members, they employ a team of employees, engage volunteers and generate revenues primarily from membership fees, donations, collections and public funds. Generally, nonprofit organizations are legally prohibited from distributing any residual earnings to their management; additionally, the managers are not allowed to pursue their own interests (Doherty et al. 2014). However, legal frameworks may vary significantly between countries. The basic categories distinguishing the aforementioned sectors are the general structural features indicated above. At the same time, they are recognizable features of the sectors described, distinguishing their identity and pointing to differences between them. ${ }^{2}$ Organizational forms that do not conform to the categories described are hybrid formations which are social enterprises.

In the nonprofit sector, the hybrid fraction usually refers to complex organizational forms that arise as voluntary, charitable and social units. The inherent feature of these entities is running a business that consists in the commercial sale of products and services (Maier et al. 2016). In this context, the emergence of hybrid forms of social

\footnotetext{
2 The characteristics presented here refer to somewhat oversimplified model types of entity representing a given sector and describing the ideal features of nonprofit and for-profit organizations (Girdon 2016).
}

organizations also represents nonprofits seeking new sources of income in order to finance their activities as well as a basic social mission (Mikołajczak 2018). They fill gaps in the area of providing broadly understood social and environmental needs, using a diverse spectrum of resources and trying to preserve the originally accepted directions of the social mission (Binder 2007).

To solve social problems, hybrid organizations implement various types of strategy (Alter 2008). Some of them focus on providing socially excluded people with jobs, thereby offering them not only remuneration for work, but also an opportunity to develop the skills and competences needed in the labor market. There are also hybrid organizations that try to improve certain social groups' standard of living by selling their products below market prices or giving them completely free of charge (Karnani et al. 2010). Those that operate as micro-loan organizations provide finance for unemployed people who seeking to improve their social position through self-employment (Battilana and Dorado 2010).

Woodside (2018) is studying hybrid organizations in the form of work-integration social enterprises (WISEs). The author has found that these entities embody both the socialmission and the market logics, which potentially contradict one another. Additionally, Garrow and Hasenfeld (2012) have examined the management of various institutional logics in a WISE. They have pointed out that such entities need to accept two different institutional identities: social service and market service. The former, which is basic, refers to activities conducted for the benefit of society by employing people who belong to groups at risk of social exclusion and by providing social- and professional-integration support. According to the logic of social service, people and entities cooperating with WISEs carry out a social mission. In turn, a market identity is expressed in a WISE's activity as an enterprise that creates jobs and generates revenues from the sale of goods or services.

When referring to the hybridity of social enterprises, Billiterri (2007) explores the structures of these organizations. He states that, as a "fourth sector" (in addition to private, public and nonprofit enterprises), social enterprises combine a charity mission, corporate methods and various socio-environmental philosophies that go beyond traditional business models and philanthropy. Regardless of the complexity of their final structure, social enterprises are increasingly turning traditional nonprofit organizations and corporate philanthropy into new hybrid organizations. The author emphasizes that social enterprises are a new generation of hybrid organizations that is taking root in the space between the corporate world (which is limited by the obligation to generate profits for shareholders) and nonprofit organizations (which often lack the market efficiency typical of commercial enterprises). Social enterprises' 
hybrid structure makes it easier for them to manage different logics, which they can combine into a unique, mixed model (Hahn et al. 2015; Smith and Lewis 2011).

As underlined by Mikołajczak (2017b), although commercial activity is of secondary importance to social priorities, its success is also determined by effects that can be measured by means of specific qualitative and quantitative indicators. By accomplishing financial and social objectives, social enterprises are therefore a classic example of hybrid organizations. The differences between both priorities are reflected, for instance, in the organizations' management style (Apostu 2013; Clark 1991), cooperation with other market participants (Ullah et al. 2006) and formulated plans or strategies (Carroll and Stater 2009; Raisiene and Urmanaviciene 2017).

The complexity of social enterprises as hybrid forms of social organizations expressing different identities and goals, as well as a different logic and practice of action, creates particular difficulties for the leaders of these organizations. Smith and Lewis (2011) argue that these difficulties arise from tensions that are created when organizations are pursuing different, or even contradictory, goals or are attempting to meet numerous stakeholders' inconsistent requirements. The goals associated with a social mission focus on the differences between the effects of the mission being targeted at a wide range of stakeholders, including employees, communities, families or business partners (Haigh and Hoffman 2012; Jäger and Schröer 2014). On the other hand, social enterprises, in addition to the goals associated with the social mission, need to take care of the objectives related to commercial activities.

According to Sanders (2015) and Ebrahim et al. (2014), the commercial aspect of hybrid organizations being a consequence of social organizations' marketization may be the cause of distortions in the fulfillment of social goals. In the researchers' view, these goals refer, for example, to an instrumental manner in which they implement a social mission (change), to the weakening of private donors' charitable activity, or to commercial income crowding out public and voluntary resources.

Raisiene and Urmanaviciene (2017) point out that, in order to obtain the necessary resources, hybrid organizations may respond to institutional demands stemming from the market logic, while failing to attend to those associated with the social-welfare logic. Smith et al. (2013) found that one challenge for hybrid organizations is to sustain commitments to both the social-welfare and the commercial logics amidst institutional pressure to prioritize the latter. Foster and Bradach (2005) argue that commercial priorities can distract nonprofits' managers from their key social missions, sometimes even subverting those missions. D'Espallier et al. (2017), who used a worldwide sample of
1151 MFIs, found that interest rates increase with aid volatility, while the average loan size (ALS) is inversely related to aid volatility. The authors suggest that MFIs consider the ALS to be a device signaling commitment to their social mission, but use interest rates as an adjustment variable to cope with uncertainty.

Chambers (2014) observes that resource providers (e.g., venture capital firms) and market conditions (e.g., increasing competition) often turn social enterprises toward rapid growth through organizational growth strategies, which may distract them from their social goals.

Lewis's (2005) findings suggest that the tension between being business-like and fulfilling a social mission exists as an ontological feature of nonprofit organizational life. In this context, Mikołajczak (2019) states that revenue on commercial activity (sale of products and services) does not play any vital role in the case of a change in NGOs' mission. Sanders and McClellan (2014) indicate that communication is a means by which the relationship and compatibility between being business-like and fulfilling the social mission are negotiated. The question arises, therefore, whether organizations combining the commercial logic and social welfare are characterized by mission volatility.

In other publications, the authors express concern that social prerequisites may be the cause of a social enterprise's dysfunctional financial efficiency (see more in: Tracey 2012; Smith et al. 2013) because, in view of the effects achieved by these entities, the commercial and social goals can be mutually exclusive. In addition, economic efficiency expressed in revenues, costs and profits is easy to identify, even in the short term. At the same time, effects in the area of social-mission execution are usually long term and often very difficult to measure (Smith et al. 2013).

\section{Materials and Methods}

Data for analysis were obtained from the Klon/Jawor Association, which commissioned the Millward Brown company to conduct a survey on a representative sample of 3800 Polish foundations and associations in the third and the fourth quarters of 2015. The research was carried out on a random group of associations and foundations drawn from the REGON GUS register (Main Statistical Office) (using December 2014 data), verified on the basis of information obtained from KRS (National Court Register) and data collected by the bazy.ngo.pl network. As part of the stratification procedure, the 1) legal form (association or foundation), 2) size of the town and 3) province in which the organization is registered were separated. Additionally, within the sample, two segments were distinguished: sports 
organizations and the largest, deliberately selected organizations. The analyses were performed using analytical weights correcting the share in the sample of entities from a particular layer and the sample segment.

The data concerning associations and foundations were collected by means of the interview method, which used two research techniques: (1) 2975 interviews were carried out employing the CAPI technique (direct interviews supported by a computer and conducted by interviewers in an area) and (2) 825 interviews were done applying the CAWI technique (an online survey). In both cases, the respondents were people performing key functions in their organizations. Therefore, the questionnaire was to be completed by the leader of the organization, a member of the senior management or a member of the trustee board or management committee.

The data were collected in compliance with the secrecy principle. As part of the report, 24 individual in-depth interviews with NGO employees and leaders were conducted. From among the subjects surveyed, the present author selected 412 organizations which perform a business activity consisting of selling products and services (social enterprises), and 3386 NGOs which do not conduct such an activity. Performing business activity and the possibility of obtaining revenue from the sales of products/services is the basic criterion for qualifying NGOs to the category of hybrid organizations-social enterprises. Hence, these two categories of NGOs were marked as dichotomic variables. At the same time, to verify the first hypothesis-the existence of significant differences in the way NGOs performing business activity operate in comparison with social organizations not performing such an activity-the dependent variables were marked from V1 to V7, namely having development plans and strategies (V1); detailed revenue and expenditure planning (V2); business cooperation (V3); stability of financial-support sources (V4); regularity of activity (V5); mission variability (V6); and adjusting policy directions to donors' changing interests (V7). The variables were classified according to selected features characterizing the functioning of NGOs on a fivedegree scale (Chan and Walmsley 1997). In order to avoid biased answers, the respondents were informed that there were no "worse" or "better" answers. For each pair of answers, they were asked to indicate which of the statements better describes the organization. The respondent could choose only one point on the scale. Only extreme responses 1 and 5 were described. Table 1 shows the composition of each variable's scale.

To verify the second hypothesis concerning the features of a successful coexistence of two different institutional logics among social enterprises-the market logic (M) and the social-welfare logic $(\mathrm{S})$-dependent variables were included: Influence of the organization on solving important social problems (S1); quality of provided social services (S2); cooperation with other similar social organizations (S3); and cooperation with local and government units (S4) are part of the social-welfare logic, while level of financial situation (M1); quality of financial management (M2); level of asset equipment (M3); and ability to compete with other entities (M4) characterize the market logic. The respondents were asked to rate issues which deal with the current situation of the organization and to what extent the description featuring in every question matches this situation. In consequence, all variables reflect the respondents' subjective perception. A five-degree scale was applied, where "1" means "very negatively," "2" "negatively," " 3 " "neither positively nor negatively," "4" "positively," and "5" "very positively." The respondent could also choose answer 7, which meant "It's hard to say" or "8"- "not applicable." However, organizations that chose one of these answers were excluded from the analysis (see Table 2).

To verify both hypotheses, a one-factor analysis of variance (ANOVA) was carried out. ANOVA is a statistical method used to study observations that depend on one or more simultaneously operating factors. The method indicates which factors may be responsible for differences between the group means observed.

As part of the one-factor variance analysis, distributionnormality research was conducted by means of a Kolmogorov-Smirnov test. For those variables which did not meet the distribution-normality criteria in the analysis, a nonparametric Kruskal-Wallis test was carried out. To check the assumption of variance homogeneity, a BrownForsythe (B-F) test was performed due to unequal group sizes. In cases where the variance-homogeneity criterion was met, an F-test was conducted to assess the differences. In other cases, a Welch test was employed to evaluate the averages.

\section{Results}

\section{Hypothesis 1}

Within the first stage, distribution-normality research was conducted for all dependent variables, with a level of $P<0.01$ reached in a Kolmogorov-Smirnov test, which gave grounds for rejecting the hypothesis about the distribution normality of the variables tested. As the condition of distribution normality for dependent variables was not met, a nonparametric Kruskal-Wallis test was employed to compare average survey values. For the Kruskal-Wallis test, the level of variables' significance from V1 to V7, except for V3 and V6, was smaller than $P=0.05$, so grounds were given for rejecting the assumption of the lack 
Table 1 Hypothesis 1variables examined

Table 2 Hypothesis 2 variables examined

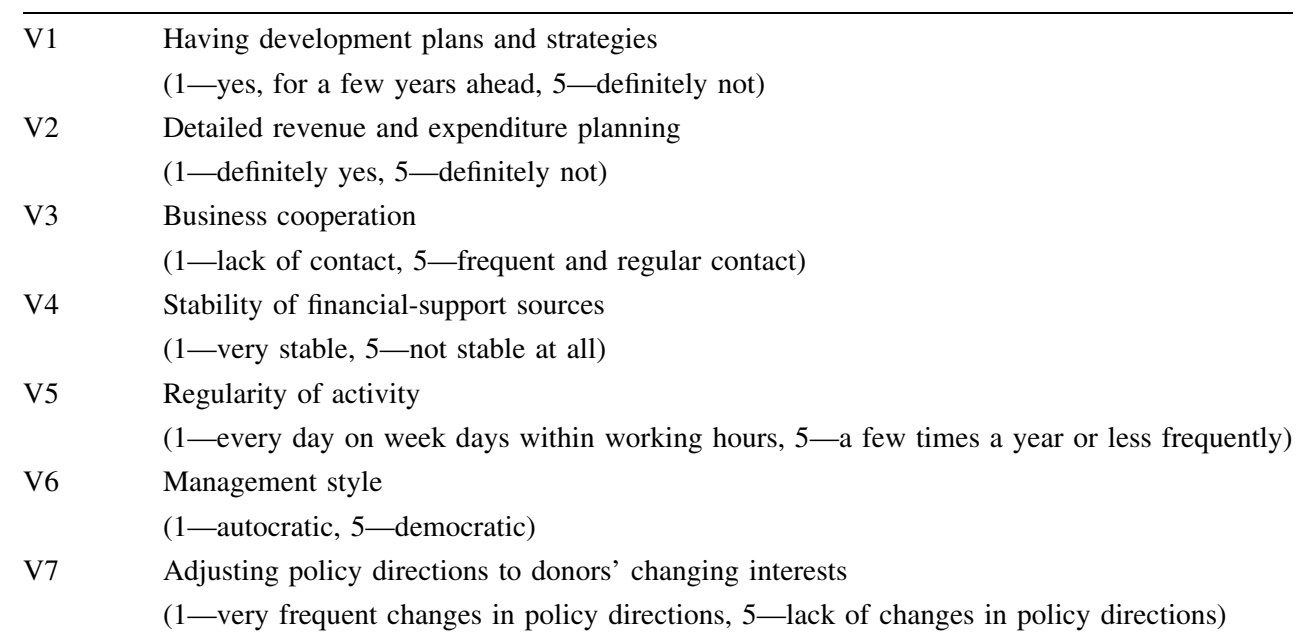

Social well-being logic

S1

$\mathrm{S} 2$

$\mathrm{S} 3$

S4

Market logic

M5

M6

M7

M8
Influence of the organization on solving important social problems Quality of provided social services

Cooperation with other organizations

Cooperation with public and local government units

Financial situation

Quality of financial management

Level of assets equipment

Ability to compete with other entities of significant differences among average results between NGOs that perform and those that do not perform business activity. For the Kruskal-Wallis test, the level of variables' significance V3 and V6 was higher than $P=0.05$, so no grounds were given for rejecting the assumption of the lack of significant differences among average results between NGOs that conduct and those that do not conduct business activity.

To check the assumption of variance homogeneity, a Brown-Forsyth test was used because of unequal group sizes (412 NGOs conducting business activity and 3386 not doing so; data shortages were tackled by not including in the analysis the NGOs concerned). The assumption of variance homogeneity was met for variables V3, V4, V6 and V7. The test result indicated variance homogeneity of variables in both NGO groups-those that perform and those that do not perform business activity $(P>0.05)$. Therefore, to evaluate averages, an F-test was used. Since, in the case of variables V1, V2 and V5, the test result showed lack of variance homogeneity in both groups $(P<0.05)$, a Welch test was employed to evaluate averages. The variance analysis showed statistically significant differences in the way NGOs performing or not performing business activity act for variables V1, V2, V4, V5 and V7.
For variables V3 and V6, there are no significant differences between the NGO groups (see Table 3).

\section{Hypothesis 2}

To identify differences in the functioning of social enterprises or NGOs not performing a business activity, a onefactor analysis of variance (ANOVA) was carried out. Within the first stage, distribution-normality research was conducted for all dependent variables, with a level of $P<0.01$ reached in a Kolmogorov-Smirnov test, which gave grounds for rejecting the hypothesis about the distribution normality of the variables tested. As the condition of distribution normality for dependent variables was not met, a nonparametric Kruskal-Wallis test was employed to compare average survey values. For the Kruskal-Wallis test, the level of variables' significance from M1 to M8, except for M2, was smaller than $P=0.05$, so grounds were given for rejecting the assumption of the lack of significant differences among average results between NGOs that perform and those that do not perform business activity. For the Kruskal-Wallis test, the level of variables' significance M2 was higher than $P=0.05$, so no grounds were given for rejecting the assumption of the lack of significant 
Table 3 ANOVA analysis-NGOs' hybridity characteristics

\begin{tabular}{|c|c|c|c|c|c|c|}
\hline \multirow[t]{3}{*}{ Variable } & \multirow{3}{*}{$\begin{array}{l}\text { NGOs conducting a business activity } \\
\text { (social enterprises) }\end{array}$} & \multirow{3}{*}{$\begin{array}{l}\text { NGOs not conducting a } \\
\text { business activity }\end{array}$} & \multicolumn{4}{|l|}{ Test } \\
\hline & & & $\begin{array}{l}\mathrm{K}- \\
\mathrm{S}\end{array}$ & $\begin{array}{l}\mathrm{K}- \\
\mathrm{W}\end{array}$ & $\mathrm{B}-\mathrm{F}$ & W \\
\hline & & & $P$ & & & $p(\mathrm{~F})$ \\
\hline $\begin{array}{l}\text { V1: Having development plans and } \\
\text { strategies }\end{array}$ & $2.81(412)$ & $2.42(3385)$ & 0.01 & 0.00 & 0.01 & $0.00(28,85)$ \\
\hline $\begin{array}{l}\text { V2: Detailed revenue and expenditure } \\
\text { planning }\end{array}$ & $2.91(407)$ & $2.68(3260)$ & 0.01 & 0.01 & 0.00 & $0.00(9,49)$ \\
\hline V3: Business cooperation & $2.48(412)$ & $2.42(3386)$ & 0.01 & 0.32 & 0.58 & $0.31(1,02)$ \\
\hline $\begin{array}{l}\text { V4: Stability of financial-support } \\
\text { sources }\end{array}$ & $2.47(406)$ & $2.90(3240)$ & 0.01 & 0.00 & 0.22 & $0.00(27,81)$ \\
\hline V5: Regularity of activity & $2.45(401)$ & $1.57(3301)$ & 0.01 & 0.00 & 0.00 & $0.00(221,25)$ \\
\hline V6: Management style & $3.16(408)$ & $3.09(3382)$ & 0.01 & 0.46 & 0.92 & $0.44(0,60)$ \\
\hline $\begin{array}{l}\text { V7: Adjusting policy directions to } \\
\text { donors' changing interests }\end{array}$ & $3.90(412)$ & $3.70(3386)$ & 0.01 & 0.00 & 0.51 & $0.00(7,94)$ \\
\hline
\end{tabular}

differences among average results between NGOs that conduct (social enterprises) and those that do not conduct business activity.

To check the assumption of variance homogeneity, a Brown-Forsyth test was used because of unequal group sizes (412 NGOs conducting business activity (social enterprises) and 3386 not doing so; data shortages were tackled by not including in the analysis the NGOs concerned) (see Table 4).

The assumption of variance homogeneity was met for variables M1, M3 and M6. The test result indicated variance homogeneity of variables in both NGO groups - those that perform and those that do not perform business activity $(P>0.05)$. Therefore, to evaluate averages, an F-test was used. Since, in the case of variables M2, M4, M5, M7 and M8, the test result showed lack of variance homogeneity in both groups $(P<0.05)$, a Welch test was employed to evaluate averages. The variance analysis showed statistically significant differences in the way NGOs performing or not performing business activity act for variables M1, M2, M3, M5, M6, M8, M9 and M10. For variable M4, there are no significant differences between the NGO groups (see Table 4).

\section{Conclusions and Further Research Directions}

The research results obtained clearly demonstrate that NGOs conducting business activity rate their social activity higher. Having analyzed the surveyed NGOs' responses concerning the assessment of their organization, it should be concluded that the social enterprises under analysis have better structured areas of operation and a clear vision of activity in comparison with NGOs that do not conduct business activity.

First of all, social enterprises declare possessing more precise development strategies and a more detailed planning of their revenues and expenses than do NGOs which do not conduct business activity. At the same time, neither meticulous plans nor precise development strategies are an inherent feature of social enterprises only; they should characterize every organization, whether or not it conducts commercial sales (e.g., Blackmon 2008; Siciliano 1996). Some researchers point out that strategic planning determines NGOs' performance (Bryson 2018; Allison and Kaye 2011). Others even argue that organizations relying primarily on commercial revenues are more efficient in managing their overheads and administrative expenses than are the nonprofits which rely mainly on donations (Ecer et al. 2017).

The research results prove that conducting business activity can be a factor that encourages NGOs to adopt a different approach and a more structured way of operating.

These observations also concern the stability and regularity of the surveyed organizations' ongoing activities. Even though, as suggested by the research results, NGOs conducting and those not conducting economic activity declare that they can, to a greater or lesser extent, count on money from the same sources, social enterprises' view is that their activity is more regular and stable. This means that they do not operate on a short-term basis to perform specific tasks, on condition that they receive public subsidies to implement their projects. The issue of NGOs' stable operation relying on public support is also raised by other researchers, particularly those from developing countries (e.g., Milelu 2018; Wachira 2016). The identified 
Table 4 ANOVA analysis-market and social well-being characteristics

\begin{tabular}{|c|c|c|c|c|c|c|}
\hline \multirow[t]{3}{*}{ Variable } & \multirow{3}{*}{$\begin{array}{l}\text { NGOs conducting a business } \\
\text { activity (social enterprises) } \\
\text { Average value/ }(N)\end{array}$} & \multirow{3}{*}{$\begin{array}{l}\text { NGOs not conducting a } \\
\text { business activity }\end{array}$} & \multicolumn{4}{|l|}{ Test } \\
\hline & & & $\begin{array}{l}\mathrm{K}- \\
\mathrm{S}\end{array}$ & $\begin{array}{l}\mathrm{K}- \\
\mathrm{W}\end{array}$ & $\mathrm{B}-\mathrm{F}$ & $p(\mathrm{~W})$ \\
\hline & & & $P$ & & & $p(\mathrm{~F})$ \\
\hline $\begin{array}{l}\text { S1: The influence of the organization on } \\
\text { solving important social problems }\end{array}$ & $3.57(98)$ & $3.28(183)$ & 0.01 & 0.03 & 0.18 & $0.00(32,16)$ \\
\hline S2: Quality of provided social services & $3,77(106)$ & $3,19(182)$ & 0.01 & 0.03 & 0.00 & $0.01(6,82)$ \\
\hline $\begin{array}{l}\text { S3: Cooperation with other similar social } \\
\text { organizations }\end{array}$ & $3,80(103)$ & $3,60(193)$ & 0.01 & 0.09 & 0.00 & $0.06(3,85)$ \\
\hline S4: Cooperation with local government units & $3,57(100)$ & $3,28(201)$ & 0.01 & 0.01 & 0.05 & $0.01(7,16)$ \\
\hline M1: Financial situation & $3.21(107)$ & $2.52(170)$ & 0.01 & 0.00 & 0.00 & $0.01(8,93)$ \\
\hline M2: Quality of financial management & $4,10(107)$ & $3,75(150)$ & 0.01 & 0.01 & 0.06 & $0.01(8,93)$ \\
\hline M3: Level of asset equipment & $3,58(106)$ & $3,97(182)$ & 0.01 & 0.01 & 0.03 & $0.00(25,20)$ \\
\hline M4: Ability to compete with other entities & $3,88(98)$ & $3,38(183)$ & 0.01 & 0.01 & 0.00 & $0.00(16,65)$ \\
\hline
\end{tabular}

feature that differentiates both groups may be crucial for this discussion, because such an approach creates a basis for the effects of the organizations' mission being sustainable (Carmin 2010; Mikołajczak 2017a). A more detailed explanation of the reasons for social enterprises' motivation may also inspire further research on these enterprises' hybridity.

The research findings also suggest that those of the social enterprises surveyed which tend to be more competitive than NGOs not conducting business activity rate their ability to cooperate with public entities more highly. This may empirically confirm some of the theoretical findings by researchers studying the hybridity of nonprofit organizations (Skelcher and Smith 2015; Katre and Salipante 2012; Galaskiewicz and Barringer 2012).

Although the NGOs combining the market logic with the social-welfare logic assess their cooperation with business positively-which is confirmed by other studies (e.g., Sakarya et al. 2012; Selsky and Parker 2005; Austin 2000) - the present study proves that cooperation with business is not a feature distinguishing social enterprises from organizations that do not conduct business activity.

Additionally, contrary to findings by other authors who emphasize the commercialization effect crowding out public support (Guo 2006), the research results suggest that social enterprises rate their relations with various partners at the local and central level (public and local government units) more highly than do NGOs not conducting business activity. Although this unresolved problem is still being hotly debated, the research results may confirm findings by researchers who point to public authorities' supportive attitude to NGOs' commercialization. An analysis of the research results to date seems to suggest that such is the specificity of Central and Eastern European as well as developing countries (Vaceková et al. 2017; Moskvina 2013; Svidronova and Vaceková 2012; Toepler and Salamon 2003).

The results of empirical analysis also demonstrate that NGOs operating as social enterprises declare a democratic management model that strongly legitimizes the social logic. Furthermore, the research also proves that, in social enterprises' view, they less often adapt the direction of their social mission to donors' interests than do their counterparts which do not conduct business activity. The research results support some researchers' findings that combining social and commercial goals does not lead to mission drift in a nonprofit organization's strategy (Barr et al. 2005; Enjolras 2002; Froelich 1999). At the same time, the research does not confirm the nature of resource providers' support stimulating this drift (Fernando and Garrido 2017; Cornforth 2014).

Polish NGOs operating as social enterprises rate their impact on solving important social problems more highly than do the other NGOs surveyed, and assess their financial situation more positively. This is also true of social enterprises' perception of the higher quality of social services on the one hand and financial management on the other.

To recapitulate, based on the case of Polish NGOs, the results of the analysis empirically confirm that the implemented social mission is rated more highly among social enterprises, which effectively combine the market logic with the social-welfare logic, than among NGOs which are not profit-oriented.

In the discussion on NGOs' hybridization in the context of institutional logics, further research efforts are needed. They would allow for a more comprehensive evaluation of the efficiency of social enterprises' combining social and 
financial outcomes. Although financial-performance indicators are well described in the literature, studies identifying the indicators of social effects of an organization's activities may be of particular value for further research. It should be additionally emphasized that the guidelines presented in this paper are the result of the surveyed entities' self-assessment, rather than an assessment of their actual performance.

The results obtained can also constitute a crucial point of departure for further research to analyze the institutional characteristics of Central and Eastern Europe; they also have an impact on the nature and manifestations of nonprofits' hybridity.

With regard to the variables, it should be acknowledged that asking NGOs' leaders with a vested interest how the organization assesses its financial or social performance could be biased. This could happen due to several psychological effects, such as the "positive illusion," which can be described as an overly optimistic viewing of oneself and of one's own role in influencing those things which appear to be positive (Rong and Wilkinson 2011). Therefore, the surveyed NGOs' successful combination of institutional logics is also an expression of a subjective perception of particular aspects characterizing their activities in the area of these logics.

\section{Compliance with Ethical Standards}

Conflict of interest The author declare that he has no conflict of interest.

Open Access This article is licensed under a Creative Commons Attribution 4.0 International License, which permits use, sharing, adaptation, distribution and reproduction in any medium or format, as long as you give appropriate credit to the original author(s) and the source, provide a link to the Creative Commons licence, and indicate if changes were made. The images or other third party material in this article are included in the article's Creative Commons licence, unless indicated otherwise in a credit line to the material. If material is not included in the article's Creative Commons licence and your intended use is not permitted by statutory regulation or exceeds the permitted use, you will need to obtain permission directly from the copyright holder. To view a copy of this licence, visit http://creativecommons. org/licenses/by/4.0/.

\section{References}

Alford, R., \& Friedland, R. (1985). Powers of theory: Capitalism, the state, and democracy. Cambridge: Cambridge University Press.

Allison, M., \& Kaye, J. (2011). Strategic planning for nonprofit organizations: A practical guide and workbook. New York: Wiley.

Alter, S. K. (2008). Social enterprise models and their mission and money relationship. In A. Nicholls (Ed.), Social entrepreneurship. New models of sustainable social change (pp. 205-232). Oxford: Oxford University Press.
Apostu, D. C. (2013). Non-governmental organization leadership and development. A review of the literature. Manager, 17, 145-161.

Austin, J. E. (2000). Strategic collaboration between nonprofits and business. Nonprofit and Voluntary Sector Quarterly, 29(1), 69-97.

Bakoš, E., Soukopová, J., \& Šelešovský, J. (2015). The historical roots of local self- government in Czech and Slovak Republics. Lex Localis-Journal of Local Self-Government, 13(1), 1-19.

Barr, A., Fafchamps, M., \& Owens, T. (2005). The governance of non-governmental organizations in Uganda. World Development, 33(4), 657-679.

Battilana, J., \& Dorado, S. (2010). Building sustainable hybrid organizations: The case of commercial microfinance organizations. Academy of Management Journal, 53(6), 1419-1440.

Billitteri, T. J. (2007). Mixing mission and business: Does social enterprise need a new legal approach? Highlights from an Aspen Institute Roundtable. Nonprofit Sector Research Fund. Retrieved September 10, 2018, from: https://www.aspeninstitute.org/sites/ default/files/content/docs/pubs/New_Legal_Forms_Report_ FINAL.pdf.

Binder, A. (2007). For love and money: Organizations creative responses to multiple environmental logics. Theory and Society, $36(6), 547-571$.

Blackmon, V. Y. (2008). Strategic planning and organizational performance: An investigation using the balanced scorecard in non-profit organizations. Capella: Capella University.

Bryson, J. M. (2018). Strategic planning for public and nonprofit organizations: A guide to strengthening and sustaining organizational achievement. New York: Wiley.

Carmin, J. (2010). NGO capacity and environmental governance in Central and Eastern Europe. Acta Politica, 45(1-2), 183-202.

Carroll, D. A., \& Stater, K. J. (2009). Revenue diversification in nonprofit organizations: Does it lead to financial stability? Journal of Public Administration Research and Theory, 19(4), 947-966.

Certo, S. T., \& Miller, T. (2008). Social entrepreneurship: Key issues and concepts. Business Horizons, 51(4), 267-271.

Chambers, L. (2014). Growing a hybrid venture: Toward a theory of mission drift in social entrepreneurship. Doctoral dissertation. University of St. Gallen.

Chan, Y., \& Walmsley, R. P. (1997). Learning and understanding the Kruskal-Wallis one-way analysis-of-variance-by-ranks test for differences among three or more independent groups. Physical Therapy, 77, 1775-1762.

Clark, J. (1991). Democratising development: The role of voluntary organisations. London: Earthscan.

Cornforth, C. (2014). Understanding and combating mission drift in social enterprises. Social Enterprise Journal, 10(1), 3-20.

D’Espallier, B., Hudon, M., \& Szafarz, A. (2017). Aid volatility and social performance in microfinance. Nonprofit and Voluntary Sector Quarterly, 46(1), 116-140.

Doherty, B., Haugh, H., \& Lyon, F. (2014). Social enterprises as hybrid organizations: A review and research agenda. International Journal of Management Reviews, 16(4), 417-436.

Ebrahim, A., Battilana, J., \& Mair, J. (2014). The governance of social enterprises: Mission drift and accountability challenges in hybrid organizations. Research in Organizational Behavior, 34, 81-100.

Ecer, S., Magro, M., \& Sarpça, S. (2017). The relationship between nonprofits' revenue composition and their economic-financial efficiency. Nonprofit and Voluntary Sector Quarterly, 46(1), 141-155.

Enjolras, B. (2002). The commercialization of voluntary sport organizations in Norway. Nonprofit and Voluntary Sector Quarterly, 31(3), 352-376. 
Evans, B., Richmond, T., \& Shields, J. (2005). Structuring neoliberal governance: The nonprofit sector, emerging new modes of control and the marketisation of service delivery. Policy and Society, 24(1), 73-97.

Fernando, G. A., \& Garrido, M. A. V. (2017). Can profit and sustainability goals co-exist? New business models for hybrid firms. Journal of Business Strategy, 38(1), 3-13.

Foster, W., \& Bradach, J. (2005). Should nonprofits seek profits? Harvard Business Review, 83(2), 92-100.

Frič, P. (2004). Political developments after 1989 and their impact on the nonprofit sector. Prague: Charles University.

Froelich, K. A. (1999). Diversification of revenue strategies: Evolving resource dependence in nonprofit organizations. Nonprofit and voluntary sector quarterly, 28(3), 246-268.

Galaskiewicz, J., \& Barringer, S. N. (2012). Social enterprises and social categories. In B. Gidron \& Y. Hasenfeld (Eds.), Social enterprises: An organizational perspective (pp. 47-70). Palgrave: Basingstoke.

Garrow, E., \& Hasenfeld, Y. (2012). Managing conflicting institutional logics: Social service versus market”. In B. Gidron \& Y. Hasenfeld (Eds.), Social enterprises: An organizational perspective (pp. 121-143). London: Palgrave/Macmillan.

Gidron, B. (2016). The dual hybridity of social enterprises for marginalized populations. Journal of Social Entrepreneurship, $8(1), 1-13$

Guo, B. (2006). Charity for profit? Exploring factors associated with the commercialization of human service nonprofits. Nonprofit and Voluntary Sector Quarterly, 35(1), 173-178.

Hahn, T., Pinkse, J., Preuss, L., \& Figge, F. (2015). Tensions in corporate sustainability: Towards an integrative framework. Journal of Business Ethics, 127(2), 297-316.

Haigh, N., \& Hoffman, A. J. (2012). Hybrid organizations: The next chapter of sustainable business. Organizational Dynamics, 41, 126-134.

Hensel, P. (2015). Competing institutional logics in management of culture. Management in Culture, 16(3), 241-251.

Jackall, R. (1988). Moral mazes: The world of corporate managers. New York: Oxford University Press.

Jäger, U. P., \& Schröer, A. (2014). Integrated organizational identity: A definition of hybrid organizations and a research agenda. VOLUNTAS: International Journal of Voluntary and Nonprofit Organizations, 25(5), 1281-1306.

Jay, J. (2013). Navigating paradox as a mechanism of change and innovation in hybrid organizations. Academy of Management Journal, 56(1), 137-159.

Karnani, A. G., Garrette, B., Kassalow, J. S. \& Lee, M. (2010). Better Vision for the Poor, (March 1, 2010). Ross School of Business Paper No. 1137. Retrieved September 12, from: https://ssrn.com/ abstract $=1569479$.

Katre, A., \& Salipante, P. (2012). Start-up social ventures: Blending fine-grained behaviors from two institutions for entrepreneurial success. Entrepreneurship Theory and Practice, 36(5), 967-994.

Korosec, R. L., \& Berman, E. M. (2006). Municipal support for social entrepreneurship. Public Administration Review, 66(3), 448-462.

Lander, M. W., Koene, B. A. S., \& Linssen, S. N. (2013). Committed to professionalism: Organizational responses of mid-tier accounting firms to conflicting institutional logics. Accounting, Organizations and Society, 38(2), 130-148.

Lewis, L. K. (2005). The civil society sector: A review of critical issues and research agenda for organizational communication scholars. Management Communication Quarterly, 19, 238-267.

Maier, F., Meyer, M., \& Steinbereithner, M. (2016). Nonprofit organizations becoming business-like a systematic review. Nonprofit and Voluntary Sector Quarterly, 45(1), 64-86.
McMullin, C., \& Skelcher, C. (2018). The impact of societal-level institutional logics on hybridity: Evidence from nonprofits organizations in England and France. Voluntas: International Journal of Voluntary and Nonprofit Organizations, 29(5), 911-924.

Mikołajczak, P. (2017a). Sources and instruments of financial support for social enterprises. Poznań: UEP.

Mikołajczak, P. (2017b). Importance of funding sources to the scale of activity of social enterprises. Finanse, Rynki Finansowe, Ubezpieczenia, 4(88), 135-144.

Mikołajczak, P. (2018). The impact of the diversification of revenues on NGOs' commercialization: Evidence from Poland. Equilibrium, 13(4), 761-779.

Mikołajczak, P. (2019). Diversification of NGOs' revenues: Implications for the mission changeability. Humanities and Social Sciences, 2, 113-120.

Milelu, E. (2018). Factors affecting financial sustainability for nongovernmental organizations in Nairobi, Kenya. Doctoral dissertation, United States International University-Africa.

Moskvina, J. (2013). Social enterprises as a tool of social and economic policy. Entrepreneurship and Sustainability Issues, $1(1), 45-54$

Pache, A. C., \& Santos, F. (2013). Inside the hybrid organization: Selective coupling as a response to conflicting institutional logics. Academy of Management Journal, 56(4), 972-1001.

Peredo, A. M., \& McLean, M. (2006). Social entrepreneurship: A critical review of the concept. Journal of World Business, 41(1), $56-65$.

Pospísili, M., Navrátil, J., \& Pejcal, J. (2014). Czech Republic. In M. Institute (Ed.), Civil society in the 'Visegrád Four': Data and literature in the Czech Republic, Hungary, Poland and Slovakia (pp. 48-93). Berlin: Maecenata Institut.

Raisiene, A. G., \& Urmanaviciene, A. (2017). Mission drift in a hybrid organization: How can social business combine its dual goals? Ekonomski Vjesnik, 2, 301-310.

Rong, B., \& Wilkinson, I. F. (2011). What do managers' survey responses mean and what affects them? The case of market orientation and firm performance. Australasian Marketing Journal (AMJ), 19(3), 137-147.

Sakarya, S., Bodur, M., Yildirim-Öktem, Ö., \& Selekler-Göksen, N. (2012). Social alliances: Business and social enterprise collaboration for social transformation. Journal of Business Research, 65(12), 1710-1720.

Sanders, M. L. (2015). Being nonprofit-like in a market economy: Understanding the mission-market tension in nonprofit organizing. Nonprofit and Voluntary Sector Quarterly, 44, 205-222.

Sanders, M. L., \& McClellan, J. G. (2014). Being business-like while pursuing a social mission: Acknowledging the inherent tensions in US nonprofit organizing. Organization, 21(1), 68-89.

Seelos, C., \& Mair, J. (2005). Social entrepreneurship: Creating new business models to serve the poor. Business Horizons, 48, $241-246$

Selsky, J. W., \& Parker, B. (2005). Cross-sector partnerships to address social issues: Challenges to theory and practice. Journal of Management, 31(6), 849-873.

Siciliano, J. I. (1996). The relationship between formal planning and performance in nonprofit organizations. Nonprofit Management and Leadership, 7(4), 387-403.

Skelcher, C., \& Smith, S. R. (2015). Theorizing hybridity: Institutional logics, complex organizations, and actor identities: The case of nonprofits. Public Admin, 93, 433-448.

Smith, W. K., Gonin, M., \& Besharov, M. L. (2013). Managing social-business tensions: A review and research agenda for social enterprise. Business Ethics Quarterly, 23(3), 407-442. 
Smith, W. K., \& Lewis, M. W. (2011). Toward a theory of paradox: A dynamic equilibrium model of organizing. Academy of Management Review, 36(2), 381-403.

Svidroňová, M., \& Vaceková, G. (2012). Current state of selffinancing of private non-profit organizations in the conditions of the Slovak Republic. Technological and Economic Development of Economy, 18(3), 438-451.

Thornton, P. H. (2004). Markets from culture: Institutional logics and organizational decisions in higher education publishing. Stanford: Stanford University Press.

Thornton, P. H., \& Ocasio, W. (2008). Institutional logics. In R. Greenwood, C. Oliver, R. Suddaby, \& K. Sahlin-Andersson (Eds.), The Sage handbook of organizational institutionalism (pp. 99-129). London: Sage.

Thornton, P. H., Ocasio, W., \& Lounsbury, M. (2012). The institutional logics perspective: A new approach to culture, structure, and process. Oxford: Oxford University Press.

Toepler, S., \& Salamon, L. M. (2003). NGO development in Central and Eastern Europe: An empirical overview. East European Quarterly, 37(3), 365.

Tracey, P. (2012). Introduction: Digital resources and textbooks for teaching social entrepreneurship and innovation. Academy of Management Learning \& Education, 11(3), 511.

Ullah, A. Z., Newell, J. N., Ahmed, J. U., Hyder, M. K. A., \& Islam, A. (2006). Government-NGO collaboration: The case of tuberculosis control in Bangladesh. Health policy and planning, 21(2), 143-155.

Vaceková, G., Valentinov, V., \& Nemec, J. (2017). Rethinking nonprofit commercialization: The case of the Czech Republic. Voluntas: International Journal of Voluntary and Nonprofit Organizations Voluntas, 28(5), 2103-2123.

Vickers, I., Lyon, F., Sepulveda, L., \& McMullin, C. (2017). Public service innovation and multiple institutional logics: The case of hybrid social enterprise providers of health and wellbeing. Research Policy, 46(10), 1755-1768.

Wachira, L. W. (2016). Factors affecting financial sustainability of local NGOs in Kenya, Kiambu County. Doctoral dissertation, KCA University.

Weisbrod, B. A. (1975). Toward a theory of the voluntary nonprofit sector in a three-sector economy. In E. Phelps (Ed.), Altruism, morality, and economic theory. New York: Springer.

Woodside, S. J. (2018). Dominant logics: US WISEs and the tendency to favor a market-dominant or social mission-dominant approach. Social Enterprise Journal, 14(1), 39-59.

Wry, T., \& York, J. G. (2017). An identity-based approach to social enterprise. Academy of Management Review, 42(3), 437-460.

Publisher's Note Springer Nature remains neutral with regard to jurisdictional claims in published maps and institutional affiliations. 